\title{
KARAKTERISASI SIFAT FISIK DAN MEKANIK PENAMBAHAN KITOSAN PADA EDIBLE FILM KARAGENAN DAN TAPIOKA TERMODIFIKASI
}

\section{(CHARACTERIZATION OF PHYSICAL AND MECHANICAL PROPERTIES OF CHITOSAN ADDED ON CARRAGEENAN AND MODIFIED TAPIOCA EDIBLE FILM)}

\author{
Guntarti Supeni, Agustina Arianita Cahyaningtyas, dan Anna Fitrina \\ Balai Besar Kimia dan Kemasan, Kementerian Perindustrian \\ Jl. Balai Kimia No.1 Pekayon, Pasar Rebo, Jakarta Timur \\ E-mail : guntartisupeni@yahoo.com
}

Received : 12 Agustus 2015; revised : 19 Agustus 2015; accepted : 27 Agustus 2015

\begin{abstract}
ABSTRAK
Penelitian tentang karakterisasi sifat fisik dan mekanik penambahan kitosan pada edible film karagenan dan tapioka termodifikasi telah dilakukan. Penelitian ini bertujuan untuk mengetahui jumlah optimal penambahan kitosan pada pembuatan edible film dari karagenan dan tapioka termodifikasi untuk kemasan makanan. Edible film dibuat dengan pencampuran larutan karagenan dengan larutan tapioka termodifikasi, kemudian ditambahkan larutan kitosan menggunakan metode casting. Variabel yang digunakan adalah jumlah larutan kitosan yang ditambahkan pada larutan edible film karagenan-tapioka termodifikasi, yaitu 1,5\%; 3\%; 4,5\%; 6\%; dan 7,5\%. Edible film yang diperoleh kemudian dilakukan pengujian ketebalan, kuat tarik, elongasi, Water Vapor Transmission Rate (WVTR), dan Scanning Electron Microscope (SEM). Hasil penelitian ini diharapkan dapat diaplikasikan sebagai bahan pengemas alternatif yang ramah lingkungan. Nilai WVTR dari edible film berguna untuk memperkirakan daya simpan kemasan terhadap produk yang dikemas. Hasil penelitian menunjukkan bahwa semakin besar penambahan jumlah kitosan pada edible film karagenan dan tapioka termodifikasi, menghasilkan ketebalan, elongasi, dan nilai laju uap air yang semakin meningkat, sedangkan kuat tarik yang dihasilkan semakin menurun. Jumlah optimal penambahan kitosan pada edible film karagenan-tapioka termodifikasi adalah 1,5\%.
\end{abstract}

Kata kunci : Edible film, Karagenan, Kitosan, Tapioka termodifikasi

\begin{abstract}
Research on the characterization of physical and mechanical properties on the addition of chitosan on carrageenan and modified tapioca edible film has been conducted. This research aims to obtain the optimal amount of chitosan addition on the carrageenan and modified tapioca edible film for food packaging. Edible films were made by mixing a solution of carrageenan with a modified tapioca solution, then added a solution of chitosan using the casting method. The variable used is the number of chitosan solution that added to a solution of carrageenan - modified tapioca edible film, which is 1.5\%; 3\%; $4.5 \%$; $6 \%$; and $7.5 \%$. Edible films were then tested thickness, tensile strength, elongation, Water Vapor Transmission Rate (WVTR), and Scanning Electron Microscope (SEM). Results of this study are expected to be applied as an alternative packaging materials that are environmentally friendly. WVTR values of edible film is useful for estimating the shelf life of the packaged product packaging. The results showed that the greater number of chitosan on carrageenan and modified tapioca edible film, produce thickness, elongation, and the value of the rate of water vapor, while the tensile strength of the resulting decreases. The optimal amount of addition of chitosan on carrageenan-modified tapioca edible film was $1.5 \%$.
\end{abstract}

Keywords : Edible film, Carrageenan, Chitosan, Modified tapioca 


\section{PENDAHULUAN}

Saat ini sampah masih menjadi masalah di negara Indonesia, salah satu sampah yang paling banyak adalah sampah plastik. Plastik dianggap lebih praktis, hampir semua aktivitas di rumah tangga maupun di tempat perbelanjaan menggunakan plastik. Konsumsi plastik di Indonesia diproyeksikan mencapai 1,9 juta ton hingga semester I tahun 2013. Jumlah tersebut meningkat sekitar 22,58\% dibandingkan semester yang sama tahun 2012 sebanyak 1,55 juta ton (Kemenperin 2013). Kemasan plastik yang umumnya digunakan dalam pengemasan produk pangan berbahan dasar minyak bumi (non renewable) melalui proses polimerisasi (Rosalina et al. 2013). Penggunaan plastik sebagai bahan kemasan ini menimbulkan permasalahan lingkungan, yaitu tidak dapat didaur ulang dan tidak dapat diuraikan secara alami oleh mikroba di dalam tanah. Plastik merupakan hasil dari sintesis petrokimia, sehingga sukar didegradasi secara alami (Akbar et al. 2013).

Upaya yang dilakukan saat ini adalah mengembangkan bahan kemasan biodegradable baru dari polimer alam karena masalah lingkungan yang terkait dengan limbah plastik kemasan sintetis. Banyak limbah pertanian, perikanan, dan industri makanan yang merupakan biopolimer potensial untuk diaplikasikan sebagai bahan pembentuk film. Protein dari kedua sumber tanaman dan hewan memiliki kemungkinan besar modifikasi fisiko kimia (Hernandez-Izquierdo and Krochta 2008). Polimer alam dapat menjadi sumber alternatif untuk perkembangan kemasan karena palatabilitas dan biodegradabilitasnya (Siracusa et al. 2008). Edible coating dan film merupakan alternatif plastik sintetis untuk aplikasi makanan dan mendapat banyak perhatian dalam beberapa tahun terakhir karena keuntungannya dibandingkan dengan film sintetis (Dhanapal et al. 2012).

Penelitian dan penggunaan edible film terus mengalami peningkatan karena memiliki keuntungan sifat dibandingkan dengan bahan kemasan biasa. Edible film mudah terurai oleh mikroorganisme (biodegradable), dapat langsung dimakan, dan dapat meningkatkan daya simpan bahan pangan, serta dapat digunakan sebagai kemasan aktif (Coma 2008). Coating atau edible film dapat dibuat dari berbagai produk natural seperti polisakarida, protein, dan lipid, dengan penambahan plasticizer dan surfaktan. Polisakarida utama yang digunakan untuk coating atau edible film antara lain kitosan, pati, alginat, karagenan, selulosa termodifikasi, pektin, dan lain-lain (Dhanapal et al. 2012).

Karagenan adalah polimer yang larut dalam air dengan rantai linier dari sebagian sulfat galaktan, dimana sangat berpotensial sebagai material pembentuk film. Polisakarida sulfat ini diekstrak dari dinding sel berbagai jenis rumput laut merah (Rhodophyceae). Pembentukan film karagenan mencakup mekanisme pembentukan gel selama pengeringan, yang mengarah ke jaringan tiga dimensi yang terbentuk oleh polisakarida-heliks ganda dan film yang solid setelah penguapan pelarut (Karbowiak et al. 2006). Film yang terbuat dari karagenan tidak begitu buram jika dibandingkan dengan film yang terbuat dari pati (Ribeiro et al. 2007).

Pati merupakan salah satu jenis polisakarida yang tersedia melimpah di alam, bersifat mudah terurai (biodegradable), mudah diperoleh, dan murah. Sifat-sifat pati juga sesuai untuk bahan edible coating atau film karena dapat membentuk film yang cukup kuat. Namun, edible film berbasis pati mempunyai kelemahan, yaitu resistensinya terhadap air rendah dan sifat permeabilitasnya terhadap uap air juga rendah karena sifat hidrofilik pati dapat mempengaruhi stabilitas dan sifat mekanisnya (Garcia et al. 2011). Untuk meningkatkan karakteristik fisik maupun fungsional dari film pati, perlu dilakukan penambahan biopolimer atau bahan lain, antara lain bahan yang bersifat hidrofobik dan atau yang memiliki sifat antimikroba. Salah satu biopolimer hidrofobik (bahan tahan air) yang direkomendasikan untuk memperbaiki karakteristik film dari pati sekaligus mempunyai aktivitas antimikroba adalah kitosan (Chillo 2008).

Kitosan telah banyak digunakan sebagai bahan pembuat biodegradable film dan pengawet pangan yang tahan terhadap mikroba. Sifat antibakteri kitosan berasal dari struktur polimer yang mempunyai gugus amin bermuatan positif, sedangkan polisakarida lain umumnya bersifat netral atau bermuatan negatif. Gugus amin kitosan dapat berinteraksi dengan muatan negatif suatu molekul seperti protein dari mikroba. Kitosan bila dicampurkan dalam media film akan terjerat di dalam matriks sehingga aktivitas mikrobanya menurun (Winarti et al. 2012).

Hasil penelitian Supeni dan Irawan tahun 2011, lembaran film karagenan yang dihasilkan masih mempunyai nilai permeabilitas terhadap uap air dan gas oksigen yang besar. Margaretha et al. 2011 juga telah melakukan penelitian 
pembuatan edible film dari karagenan, namun hasil nilai permeabilitasnya juga masih besar. Salah satu upaya untuk memperbaiki sifat dari edible film adalah dengan mencampurkan pati dari tapioka dalam proses pembuatannya. Untuk itu perlu dilakukan penelitian pembuatan edible film dari karagenan dan tapioka termodifikasi, mengingat tapioka terdiri dari amilosa dan amilopektin. Amilosa (rantai lurus dan stabil) dan amilopektin (rantai bercabang) terkandung di dalam tapioka, sehingga diharapkan dengan modifikasi tapioka dengan cara hidrolisis maka kadar amilosa dalam tapioka dapat meningkat dan pada akhirnya edible film yang dihasilkan lebih stabil dan berdampak pada peningkatan sifat permeabilitasnya. Selain itu ditambahkan pula kitosan untuk memperbaiki karakteristik film, sekaligus mempunyai aktivitas antimikroba.

Penelitian ini bertujuan untuk mengetahui jumlah optimal penambahan kitosan pada pembuatan edible film dari karagenan dan tapioka termodifikasi untuk kemasan makanan.

\section{BAHAN DAN METODE}

\section{Bahan}

Bahan yang digunakan dalam penelitian ini antara lain karagenan jenis semi refined carrageenan tipe kappa dari PT Galic Artabahari, kitosan dari PT Vital House Ltd, tapioka cap Dua Angsa, asam asetat glacial dari MERCK, natrium asetat dari MERCK, etanol dari MERCK, akuades, dan gliserol teknis dari PT Brataco.

Peralatan yang digunakan untuk penelitian ini yaitu hot plate dengan stirer, termometer, pompa vakum merek MDI, beaker glass, gelas ukur, hygrometer merk Barigo, Universal Testing Machine Auto Strain merek Yasuda Seiki, labu erlenmeyer, pipet volume, kertas saring, corong penyaring vakum, media cetak (akrilik), dan neraca.

\section{Metode}

Penelitian ini dilakukan dalam 2 tahap, yaitu pembuatan edible film dan pengujian sifat fisik serta mekanik edible film.

\section{Tahap Pembuatan Edible Film Pembuatan Tapioka Termodifikasi}

Tepung tapioka sebanyak 100 gram dihidrolisis menggunakan $200 \mathrm{~mL}$ larutan asetat $\left(\mathrm{CH}_{3} \mathrm{COOH}+\mathrm{CH}_{3} \mathrm{COONa}\right) \mathrm{pH}$ 7. Campuran tepung tapioka dan larutan asetat kemudian diaduk dan dipanaskan di atas hot plate stirrer pada suhu $40{ }^{\circ} \mathrm{C}$ sampai campuran mengental. Setelah mengental, tapioka termodifikasi kemudian dikeringkan pada suhu ruang. Setelah kering, tapioka termodifikasi dihaluskan kemudian diayak menggunakan ayakan 80 mesh.

\section{Pembuatan Larutan Tapioka Termodifikasi}

Tepung tapioka termodifikasi sebanyak $7,5 \mathrm{~g}$ dilarutkan di dalam $100 \mathrm{ml}$ aquadest dan $45 \mathrm{ml}$ alkohol, kemudian dipanaskan serta diaduk di atas hot plate stirrer pada suhu $60{ }^{\circ} \mathrm{C}$ sampai dengan $70{ }^{\circ} \mathrm{C}$.Setelah mengental, kemudian ditambahkan 1,2 $\mathrm{ml}$ gliserol dan tetap dipanaskan serta diaduk sampai tergelatinisasi dan homogen.

\section{Pembuatan Larutan Karagenan}

Karagenan sebanyak $3 \mathrm{~g}$ dilarutkan di dalam $100 \mathrm{~mL}$ aquadest, kemudian dipanaskan dan diaduk di atas hot plate stirrer pada suhu $90{ }^{\circ} \mathrm{C}$ sampai dengan $100^{\circ} \mathrm{C}$.Setelah mengental, kemudian ditambahkan $15 \mathrm{ml}$ gliserol dan tetap dipanaskan serta diaduk sampai tergelatinasi dan homogen.

\section{Pembuatan Larutan Kitosan}

Kitosan sebanyak 3 gram dilarutkan di dalam $100 \mathrm{~mL}$ asam asetat 1\%, kemudian dipanaskan dan diaduk di atas hot plate stirrer pada suhu $50{ }^{\circ} \mathrm{C}$ selama 60 menit. Larutan kitosan kemudian divakum dan disaring dengan bantuan pompa vakum, agar gelembung udara dan kotoran yang terperangkap di dalam larutan kitosan dapat hilang. Larutan kitosan kemudian dipanaskan kembali pada suhu $50{ }^{\circ} \mathrm{C}$ selama 15 menit, selama pemanasan tetap dilakukan pengadukan dan penambahan plasticizer (gliserol). Setelah batas waktu 15 menit tercapai, diharapkan campuran telah homogen.

\section{Pembuatan Edible Film Karagenan - Tapioka Termodifikasi - Kitosan}

Larutan tapioka termodifikasi dan larutan karagenan yang sudah tergelatinisasi dicampur ke dalam gelas beaker dengan konsentrasi larutan tapioka termodifikasi sebanyak $75 \mathrm{~mL}$ dan larutan karagenan sebanyak $25 \mathrm{~mL}$. Larutan karagenan-tapioka termodifikasi diaduk dan dipanaskan di atas hot plate stirrer selama 1 jam supaya homogen, pada suhu $65{ }^{\circ} \mathrm{C}$. Setelah 1 jam, larutan karagenan-tapioka termodifikasi ditambahkan dengan larutan kitosan secara sedikit demi sedikit menggunakan pipet volume dengan tetap dipanaskan di atas hot plate stirrer sambil terus diaduk menggunakan pengaduk gelas. Variabel penambahan larutan kitosan yaitu $1,5 \% ; \quad 3 \% ; \quad 4,5 \% ; \quad 6 \% ;$ dan $7,5 \%$ (persentase terhadap volume larutan). Larutan edible film yang terbentuk kemudian dituangkan ke media cetak (akrilik) dengan ukuran 
$20 \mathrm{~cm} \times 20 \mathrm{~cm}$, kemudian edible film didinginkan pada suhu ruang selama kurang lebih $2 \times 24$ jam. Pendinginan ini dimaksudkan agar larutan edible film tersebut membeku dan membentuk lembaran edible film. Lembaran edible film kemudian dikelupas dari media cetak, untuk kemudian dilakukan pengujian terhadap karakteristik sifat fisik dan mekanik edible film tersebut.

\section{Tahap Pengujian Sifat Fisik dan Mekanik Edible Film}

Untuk mengetahui karakteristik dari edible film yang telah dibuat, perlu adanya pengujian sifat fisik dan mekanik dari edible film tersebut. Adapun pengujian sifat fisik dan mekanik dari edible film tersebut meliputi ketebalan, kuat tarik, elongasi, WVTR, dan SEM.

\section{Pengujian Ketebalan}

Edible film yang dihasilkan diukur ketebalannya dengan menggunakan pengukur ketebalan Micro-cal messmer dengan ketelitian $0,0001 \mathrm{~mm}$ pada lima tempat yang berbeda. Nilai ketebalan diukur dari rata-rata lima pengukuran ketebalan edible film.

\section{Pengujian Kuat Tarik Dan Persentase Pemanjangan (Elongasi)}

Kuat tarik dan persentase pemanjangan diukur dengan menggunakan Universal Testing Machine Auto Strain merek Yasuda Seiki. Kuat tarik ditentukan berdasarkan beban maksimum pada saat film putus dan persentase pemanjangan didasarkan atas pemanjangan film saat film putus. Persamaan untuk kuat tarik dan elongasi adalah sebagai berikut :

$$
\begin{aligned}
& \text { Kuat Tarik }=\frac{\text { Gaya }(F)}{\text { Luas permukaan }(A)} \\
& \% \text { Elongasi }=\frac{A-B}{B} \times 100 \%
\end{aligned}
$$

Keterangan : $A=$ panjang setelah putus

$$
\mathrm{B}=\text { panjang sebelum putus }
$$

\section{Pengujian WVTR}

WVTR edible film diukur dengan menggunakan metode gravimetri. Bahan penyerap uap air (desikan) diletakkan dalam mangkuk alumunium, kemudian sampel diletakkan di atas mangkuk tersebut sedemikian rupa sehingga menutupi mangkuk tersebut. Tuangkan lilin cair untuk menutupi bagian antara wadah dengan sampel sehingga tidak ada udara masuk (Supeni dan Irawan 2012).

Cawan ditimbang dengan ketelitian 0,0001 gram kemudian diletakkan dalam humidity chamber Yamato $\mathrm{IH}-42 \mathrm{H}$, ditutup lalu kipas angin dijalankan. Cawan ditimbang tiap hari pada jam yang sama dan ditentukan penambahan berat dari cawan. Selanjutnya dibuat grafik hubungan antara pertambahan berat dan waktu, nilai WVTR dihitung dengan rumus berikut (Supeni dan Irawan 2012) :

$$
\begin{aligned}
\text { WVTR } & =\text { slope / luas sampel } \times 100 \times 100 \mathrm{~m}^{2} \\
& =\mathrm{g} / \mathrm{m}^{2} / 24 \text { jam }
\end{aligned}
$$

\section{Pengujian Sifat Fisik}

Pengujian sifat fisik edible film yang dihasilkan dilakukan menggunakan Scanning Electron Microscope (SEM). SEM merupakan mikroskop yang bekerja berdasarkan prinsip emisi elektron pada sampel yang diiradiasi. Sampel yang diuji menggunakan SEM harus merupakan sampel kering. Pengujian SEM dilakukan di BATAN dan Metalurgi FTUI.

\section{HASIL DAN PEMBAHASAN}

\section{Hasil Pengujian Ketebalan}

Hasil pengujian ketebalan menunjukkan bahwa edible film karagenan-tapioka termodifikasi yang ditambahkan kitosan memiliki nilai ketebalan terendah 46,1 $\mu \mathrm{m}$ dan tertinggi sebesar 84,47 $\mu \mathrm{m}$ (Gambar 1). Hasil pengukuran tersebut memperlihatkan adanya kecenderungan peningkatan rata-rata ketebalan edible film dengan adanya penambahan kitosan.

Peningkatan konsentrasi bahan yang digunakan akan meningkatkan total padatan yang terdapat dalam edible film setelah dikeringkan, sehingga akan menghasilkan film yang semakin tebal. Selain dipengaruhi oleh komponen penyusun edible film, ketebalan edible film juga dipengaruhi oleh luas plat cetakan dan volume larutan film yang dicetak.

Peningkatan ketebalan edible film disebabkan adanya perbedaan konsentrasi kitosan yang digunakan sedangkan volume larutan edible film yang dituangkan dalam fleksiglas sama, sehingga akan meningkatkan total padatan dan polimer penyusun matriks edible film. Perbedaan ketebalan film tersebut disebabkan komposisi formula film yang berbeda. Semakin tinggi konsentrasi kitosan yang ditambahkan, maka viskositasnya juga akan meningkat sehingga edible film yang terbentuk akan semakin tebal.

Viskositas edible film setelah pemanasan merupakan kontrol yang mempengaruhi 
ketebalan edible film selain plat pencetaknya (Kusumawati dan Putri 2013).

\section{Hasil Pengujian Kuat Tarik}

Kekuatan tarik merupakan parameter penting yang berpengaruh terhadap sifat mekanik edible film. Sifat mekanik dapat berupa kekuatan, kekerasan, kekakuan, dan keliatan. Kekuatan tarik adalah tegangan regangan maksimum sampel sebelum putus.

Hasil pengujian kuat tarik menunjukkan bahwa semakin banyak kitosan yang ditambahkan, maka kekuatan tarik edible film cenderung menurun (Gambar 2). Nilai kuat tarik terendah yang diperoleh yaitu $3,39 \mathrm{kgf} / \mathrm{cm}^{2}$ dan nilai tertinggi $5,05 \mathrm{kgf} / \mathrm{cm}^{2}$.

Kekuatan tarik dari edible film yang terbentuk cenderung menurun, hal ini kemungkinan dikarenakan adanya kitosan yang mengganggu pembentukan matriks film oleh polimer pati tapioka dan karagenan. Kitosan mengandung komponen zat terlarut yang masuk ke dalam jaringan tiga dimensi matriks film sehingga memperlemah ikatan antar polimer (Kusumawati dan Putri 2013).

Sifat kekuatan tarik merupakan sifat fisik yang berhubungan dengan kekuatan edible film untuk menahan kerusakan fisik pada saat pengemasan bahan pangan. Edible film dengan nilai kekuatan tarik paling tinggi diharapkan dapat menahan kerusakan fisik maksimal, sehingga kerusakan yang akan diterima produk menjadi minimal. Edible film dengan kekuatan tarik tinggi akan mampu melindungi produk yang dikemasnya dari gangguan mekanis dengan baik (Sara 2015).

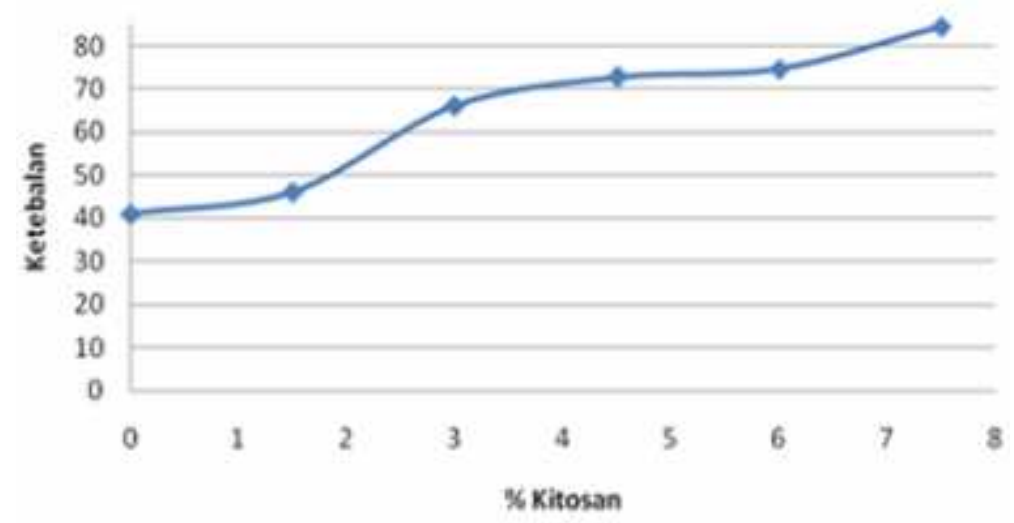

Gambar 1. Hasil uji ketebalan edible film

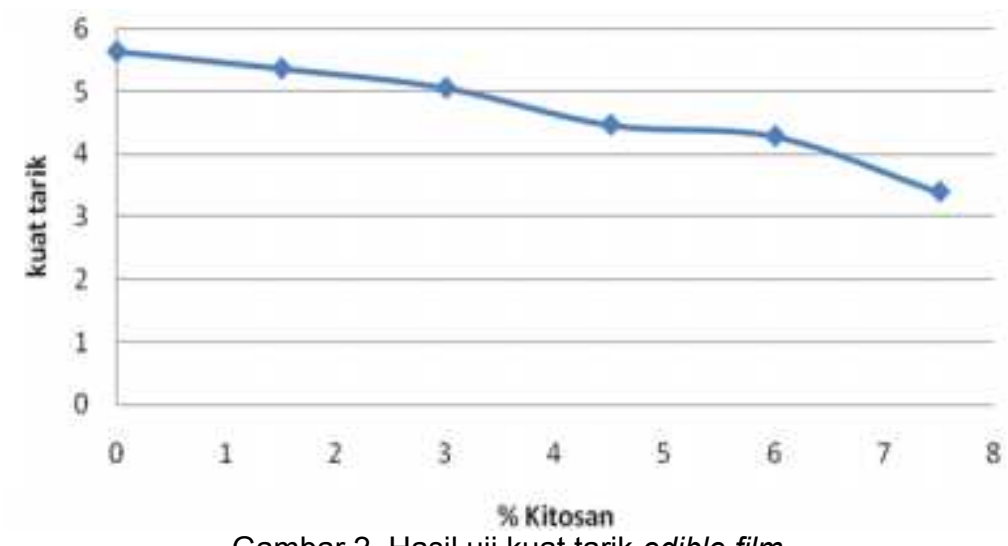

Gambar 2. Hasil uji kuat tarik edible film 


\section{Hasil Pengujian Persentase Pemanjangan (Elongasi)}

Pengukuran kekuatan tarik edible film biasanya diikuti dengan pengukuran persentase pemanjangan, yaitu perubahan panjang maksimum yang dialami edible film ketika pengujian kekuatan tarik yang dilihat saat edible film putus. Hasil pengujian persentase pemanjangan (elongasi) edible film ditunjukkan pada Gambar 3.

Berdasarkan Gambar 3 terlihat bahwa pada konsentrasi penambahan kitosan yang meningkat menyebabkan persentase pemanjangannya juga akan lebih besar. Adanya kenaikan elongasi dipengaruhi oleh adanya gliserol. Gliserol berperan sebagai plasticizer sehingga edible film menjadi lebih elastis. Gliserol memiliki berat molekul yang kecil sehingga dapat masuk ke dalam ikatan antarmolekul amilosa atau bahkan diantara ikatan hidrogen pati tapioka dengan karagenan. Molekul gliserol akan mengganggu kekompakan pati tapioka, menurunkan interaksi intermolekuler dan meningkatkan mobilitas polimer sehingga mengakibatkan peningkatan elongasi. Keberadaan dari plasticizer di dalam film bisa menyela pembentukan double helix dari amilosa dengan cabang amilopektin, lalu mengurangi interaksi antara molekul-molekul amilosa dan amilopektin, sehingga meningkatkan fleksibilitas film (Zhang and Han 2006).

\section{Hasil Pengujian WVTR}

WVTR adalah jumlah uap air yang melalui permukaan film per luas area. Hasil pengujian WVTR menunjukkan bahwa peningkatan konsentrasi larutan kitosan yang ditambah, mengakibatkan peningkatan laju transmisi uap air dari edible film karagenan-tapioka termodifikasi-kitosan (Gambar 4).

Transmisi terdiri dari proses pelarutan dan difusi aktif dimana uap air yang larut di satu sisi film berdifusi dan kemudian melalui sisi lain. Kecepatan daya tahan untuk transmisi uap air ditentukan oleh ketebalan, suhu, dan gradien tekanan parsial uap air (Saputra et al. 2015). Nilai transmisi uap air edible film yang ditambahkan larutan kitosan memiliki nilai terendah $24,41 \mathrm{~g} / \mathrm{m}^{2} / 24$ jam dan nilai tertinggi $32,03 \mathrm{~g} / \mathrm{m}^{2} / 24 \mathrm{jam}$ (Gambar 4). Nilai transmisi uap air yang diperoleh masih tinggi dikarenakan laju transmisi uap air tergantung pada perbandingan bahan yang bersifat hidrofilik dan hidrofobik dalam formulasi edible film. Umumnya edible film yang terbuat dari bahan protein dan polisakarida mempunyai nilai transmisi uap air yang tinggi. Protein merupakan polimer polar dan mempunyai jumlah ikatan hidrogen yang besar, sehingga menghasilkan penyerapan air pada kelembaban tinggi. Penyerapan air akan mengganggu interaksi rantai molekuler, yang kemudian diikuti dengan peningkatan difusifitas dan mampu menyerap uap air dari udara (Herliany et al. 2013).

\section{Hasil Pengujian Sifat Fisik}

Struktur mikroskopik edible film diobservasi dengan menggunakan SEM untuk mengetahui struktur internal edible film. Berdasarkan hasil pengujian SEM (Gambar 5), memperlihatkan struktur polimer edible film kitosan berupa polimer serat panjang dan mempunyai pori yang besar.

Penambahan jumlah kitosan ke dalam larutan edible film karagenan-tapioka termodifikasi mempengaruhi laju transmisi uap air. Pada penambahan kitosan $1,5 \%$ ke dalam larutan edible film karagenan dan tapioka termodifikasi menghasilkan nilai WVTR yang optimal, hal ini disebabkan kitosan yang ditambahkan sudah merata mengisi pori-pori atau celah ikatan antar polimer yang terbentuk (Gambar 6).

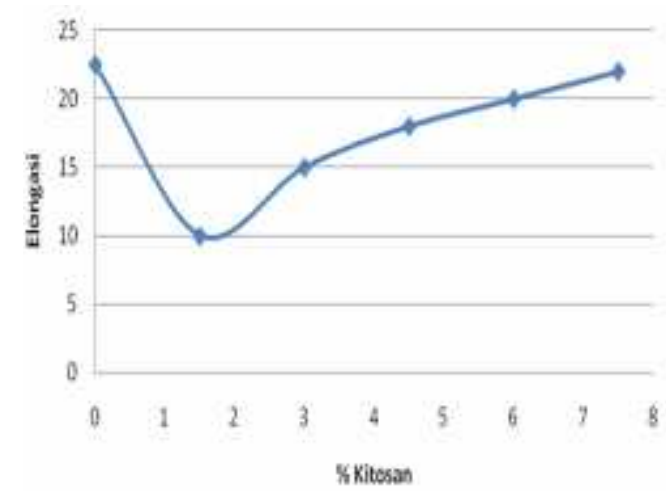

Gambar 3. Hasil uji elongasi edible film

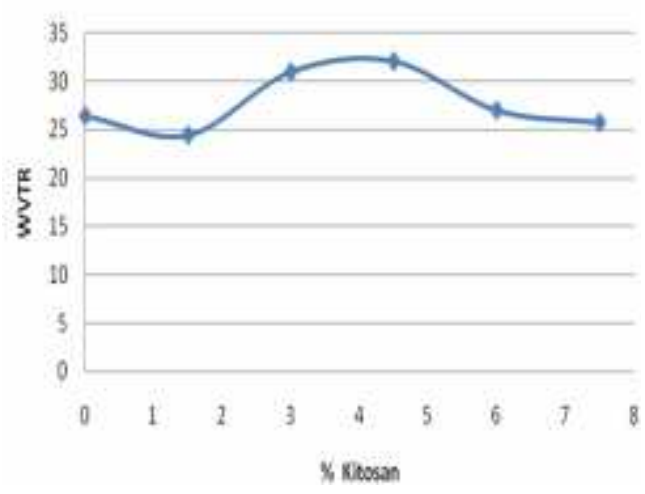

Grafik 4. Hasil uji WVTR edible film 
Pada edible film karagenan-tapioka termodifikasi yang tanpa penambahan jumlah kitosan, dari hasil SEM menunjukkan bahwa pada edible film terlihat pori-pori lebih banyak, mikrostruktur yang lebih kasar dan terbuka sehingga menghasilkan laju transmisi uap air yang lebih tinggi jika dibandingkan dengan yang ditambahkan kitosan 1,5\% (Gambar 7). Laju transmisi uap air ini berpengaruh terhadap keawetan dari bahan makanan yang akan dikemas. Semakin kecil laju transmisi uap air maka bahan makanan yang dikemas akan lebih awet.

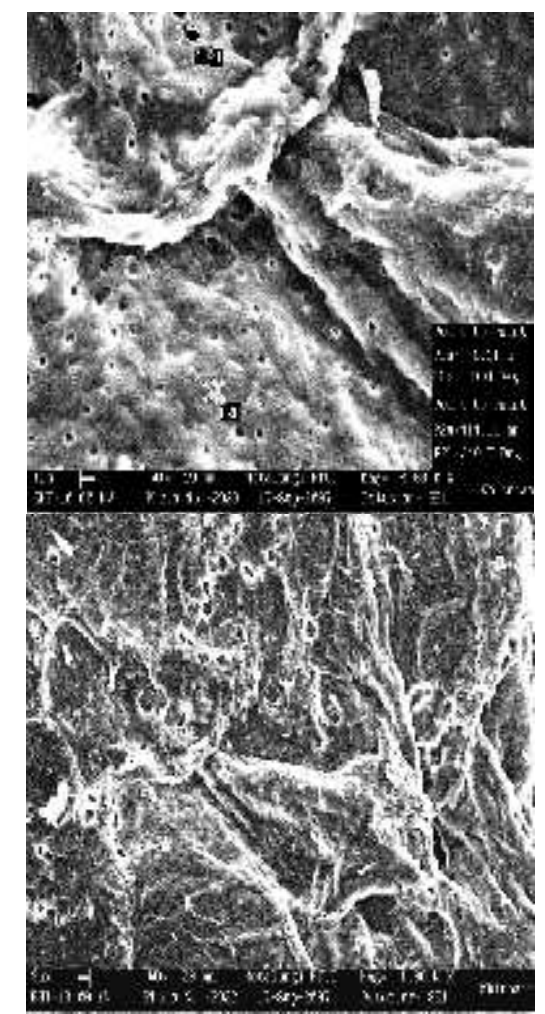

Gambar 5. Hasil SEM edible film kitosan

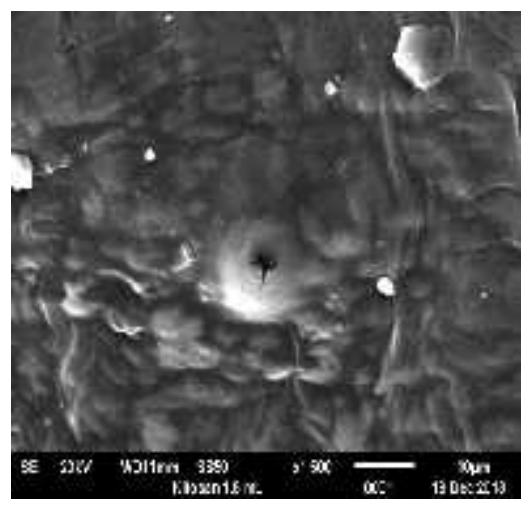

Gambar 6. Hasil SEM edible film karagenan-tapioka termodifikasi dengan penambahan kitosan $1,5 \%$

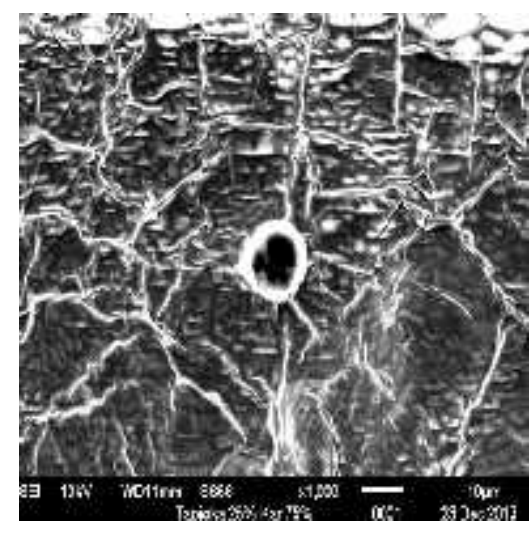

Gambar 7. Hasil SEM edible film karagenan-tapioka termodifikasi tanpa penambahan kitosan

\section{KESIMPULAN}

Semakin besar jumlah kitosan yang ditambahkan pada edible film karagenan dan tapioka termodifikasi menghasilkan ketebalan, elongasi, dan nilai laju uap air yang semakin meningkat, sedangkan kuat tarik yang dihasilkan semakin menurun. Dari hasil pengujian ketebalan, kuat tarik, elongasi, dan WVTR diperoleh jumlah optimal penambahan kitosan pada edible film karagenan dan tapioka termodifikasi sebesar $1,5 \%$.

\section{DAFTAR PUSTAKA}

Akbar, F., Z. Anita, dan H. Harahap. 2013. Pengaruh waktu simpan film plastik biodegradasi dari pati kulit singkong terhadap sifat mekanikalnya. Jurnal teknik kimia USU 2 (2) : 11-15.

Chillo, S., S. Flores, M. Mastromatteo, A. Conte, Lýa Gerschenson, and M.A. del Nobile. 2008. Influence of glycerol and chitosan on tapioca starch-based edible film properties. J. Food Engin. 88: 159-168.

Coma, V. 2008. Bioactive packaging technologies for extended shelf-life of meat based products. Meat science 78 : 90-103.

Dhanapal, A., P. Sasikala, L. Rajamani, V. Kavitha, G. Yazhini, and M.S. Banu. 2012. Edible films from polysaccharides. Food science and quality management $3: 9-18$.

Garcia, N.L., L. Ribbon, A. Dufresne, M. Aranguren, and S. Goyanes. 2011. Effect of glycerol on the morphology of nanocomposites made from thermoplastic starch and starch 
nanocrystals. Carbohydrate polymers 84 (1): 203-210.

Herliany, N. E., J. Santoso, dan E. Salamah. 2013. Karakteristik biofilm berbahan dasar karagenan. Jurnal akuatika 4(1) : 10-20.

Hernandez-Izquierdo, V. M. and J. M. Krochta. 2008. Thermoplastic processing of proteins for film formation - a review. J. Food Sci.73 : 30-39.

Karbowiak, T., F. Debeaufort, D. Champion, and A. Voilley. 2006. Wetting properties at the surface of iota-carrageenan-based edible films. J colloid interface sci 294 : 400-410.

Kemenperin. 2013. Semester I, Konsumsi Plastik 1,9 Juta Ton. http://www.kemenperin.go.id/artikel/62 62/Semester-I,-Konsumsi-Plastik-1,9Juta-Ton. (diakses pada 15 September 2015)

Kusumawati, D.H. dan W. D. R. Putri. 2013. Karakteristik fisik dan kimia edible film pati jagung yang diinkorporasi dengan perasan temu hitam. Jurnal pangan dan agroindustri 1 (1) : 90-100.

Margaretha, J.P., K.W.R. Manduapessy, dan S. Hadinoto. 2011. Aplikasi penggunaan tepung karaginan pada produk fish nugget dari daging merah ikan tuna. Laporan Penelitian. Baristan Ambon.

Ribeiro, C., A. A. Vicente, J. A. Teixeira, and C. Miranda. 2007. Optimization of edible coating composition to retard strawberry fruit senescence. Postharvest Biol. Tec. 44 : 63-70.

Rosalina, L., Hendaryanto, E.T. Kurniawaty, F. Mohammad, N.E. Putri, G.H. Pramono, Dheny T.W.S., Y.H. Ramadhani, W.
Pranowo, I.F. Suhelmi, D. Purbani, H.Y. Siry, Mahdan, O.N. Marwayana, Y. Darlan, Y. Permanawati, A. Sudaryanto, M. Hutomo, H.A. Susanto, E. riani, dan M. Khazali. 2013. Deskripsi peta ekoregion laut Indonesia. Jakarta : Balitbang KP-KKP.

Saputra, E., Kismiyati, H. Pramono, A. A. Abdillah, dan M. A. Alamsjah. 2015. An edible film characteristic of chitosan made from shrimp waste as a plasticizer. Journal of natural sciences research 5 (4) : 118-124.

Sara, N. E. M. 2015. Karakteristik edible film berbahan dasar whey dangke dan agar dengan penambahan konsentrasi sorbitol. Skripsi. Universitas Hasanuddin, Makassar. Indonesia

Siracusa, Rocculi, Romani, and Rosa. 2008. Strategies for evaluation of edible coating formulation. Appications on food quality and safety : 8 - 14.

Supeni G. dan S. Irawan. Pembuatan edible film dari karagenan. Laporan Akhir. Balai Besar Kimia dan Kemasan.

Supeni, G. dan S. Irawan. 2012. Pengaruh penggunaan kitosan terhadap sifat barrier edible film tapioka termodifikasi. Jurnal kimia dan kemasan 34 (1) : 199206.

Winarti, C., Miskiyah, dan Widaningrum. 2012. Teknologi produksi dan aplikasi pengemas edible antimikroba berbasis pati. J. Litbang Pert. 31 (3) : 85-93.

Zhang, V. and J.H. Han. 2006. Plasticization of pes starch film with monosaccharide and polyols. Jurnal Food ist. 71 (6) : E $253-\mathrm{E} 26$. 